\title{
Natural Variation in the Control of Flowering and Shoot Architecture in Diploid Fragaria Species
}

\author{
Guangxun Fan ${ }^{1}$, Javier Andrés ${ }^{1}$, Klaus Olbricht ${ }^{2}$, Elli Koskela ${ }^{1}$ and Timo Hytönen ${ }^{1,3 *}$ \\ ${ }^{1}$ Department of Agricultural Sciences, Viikki Plant Science Center, University of Helsinki, Helsinki, Finland, ${ }^{2}$ Thaer-Institute for \\ Agricultural and Horticultural Sciences, Humboldt-Universität zu Berlin, Berlin, Germany, ${ }^{3}$ Department of Genetics, Genomics \\ and Breeding, NIAB EMR, Kent, United Kingdom
}

OPEN ACCESS

Edited by:

Fernando Andrés,

INRA UMR Amélioration Génétique et

Adaptation des Plantes

Méditerranéennes et Tropicales,

France

Reviewed by:

Chunying Kang,

Huazhong Agricultural University,

China

Thomas M. Davis,

University of New Hampshire,

United States

*Correspondence: Timo Hytönen

timo.hytonen@helsinki.fi

Specialty section:

This article was submitted to

Plant Physiology,

a section of the journal

Frontiers in Plant Science

Received: 10 December 2021 Accepted: 04 February 2022

Published: 24 February 2022

Citation:

Fan G, Andrés J, Olbricht K, Koskela E and Hytönen T (2022) Natural Variation in the Control of Flowering and Shoot Architecture in Diploid Fragaria Species.

Front. Plant Sci. 13:832795. doi: 10.3389/fp/s.2022.832795
In perennial fruit and berry crops of the Rosaceae family, flower initiation occurs in late summer or autumn after downregulation of a strong repressor TERMINAL FLOWER1 (TFL1), and flowering and fruiting takes place the following growing season. Rosaceous fruit trees typically form two types of axillary shoots, short flower-bearing shoots called spurs and long shoots that are, respectively, analogous to branch crowns and stolons in strawberry. However, regulation of flowering and shoot architecture differs between species, and environmental and endogenous controlling mechanisms have just started to emerge. In woodland strawberry (Fragaria vesca L.), long days maintain vegetative meristems and promote stolon formation by activating TFL1 and GIBBERELLIN 20-OXIDASE4 (GA200x4), respectively, while silencing of these factors by short days and cool temperatures induces flowering and branch crown formation. We characterized flowering responses of 14 accessions of seven diploid Fragaria species native to diverse habitats in the northern hemisphere and selected two species with contrasting environmental responses, Fragaria bucharica Losinsk. and Fragaria nilgerrensis Schlecht. ex J. Gay for detailed studies together with Fragaria vesca. Similar to F. vesca, short days at $18^{\circ} \mathrm{C}$ promoted flowering in $F$. bucharica, and the species was induced to flower regardless of photoperiod at $11^{\circ} \mathrm{C}$ after silencing of TFL 1. F. nilgerrensis maintained higher TFL 1 expression level and likely required cooler temperatures or longer exposure to inductive treatments to flower. We also found that high expression of GA200x4 was associated with stolon formation in all three species, and its downregulation by short days and cool temperature coincided with branch crown formation in F. vesca and F. nilgerrensis, although the latter did not flower. F. bucharica, in contrast, rarely formed branch crowns, regardless of flowering or GA200x4 expression level. Our findings highlighted diploid Fragaria species as rich sources of genetic variation controlling flowering and plant architecture, with potential applications in breeding of Rosaceous crops.

Keywords: Fragaria, flowering, axillary bud, temperature, photoperiod, TERMINAL FLOWER1, GA20ox4, Rosaceae 


\section{INTRODUCTION}

The Rosaceae family contains economically important perennial crops, ranging from herbaceous species, such as strawberries (Fragaria spp.) to fruit trees like apples (Malus $\times$ domestica Borkh.) or peaches [Prunus persica (L.) Batsch; Kurokura et al., 2013]. In strawberries and Rosaceous fruit trees, floral induction takes place during summer or autumn, and flower initials continue developing until late autumn. As the season advances toward winter, these species gradually enter a period of dormancy that is broken during winter after a genetically determined period of cold temperatures called chilling requirement. As the growing season begins in the spring, vegetative growth resumes and blooming occurs (Wilkie et al., 2008; Bangerth, 2009; Kurokura et al., 2013; Costes et al., 2014). Similarities in the seasonal growth cycles of strawberries and Rosaceous fruit trees suggest that species, such as woodland strawberry (F. vesca L.) and other diploid strawberries, may be successfully used as models for studying developmental events during the seasonal cycle.

The cues required for floral induction and subsequent floral initiation differ from species to species and may depend on environmental, developmental, agricultural, or genetic factors. For instance, in apple and sweet cherry (Prunus avium L.), floral initiation depends on temperature, with species-specific optima (Sønsteby and Heide, 2019; Heide et al., 2020). In the perennial herbaceous model species $F$. vesca, floral induction is highly dependent on the interaction of temperature and photoperiod, and natural populations exhibit differences in their responses to these environmental cues. In some populations, cool temperature of $9^{\circ} \mathrm{C}$ is sufficient to induce flowering independently of photoperiod, whereas in other populations grown at cool temperature, the promoting effect of short days (SD) is evident (Heide and Sønsteby, 2007). Moreover, a population sampled from the North of Norway shows a strikingly altered yearly growth cycle with an obligatory requirement for vernalization (Heide and Sønsteby, 2007; Koskela et al., 2017). Given that such variation in environmental responses exists within a single species, it is imaginable that extending these studies to other related diploid strawberry species could reveal further adaptations to local environments. Characterizing the available diversity within the Fragaria genus may prove useful not only for researchers but also for breeders looking for novel breeding targets to improve climatic adaptation of Rosaceous crops.

As developmental events depend on the timing of meristem differentiation and the meristematic fate itself, studies on meristem fate may provide insights into climatic adaptation of plants. In Rosaceous species, shoot apical meristems (SAMs) located at shoot tips can either generate new vegetative tissues, develop terminal inflorescences, or in some species abort spontaneously (Costes et al., 2014). Meristems located in leaf axils develop axillary buds (AXBs), which can remain latent, develop into vigorously growing long shoots (called stolons in strawberries) or into short shoots (also known as spurs or dwarf shoots in fruit trees and branch crowns in strawberries) with limited extension growth and a rosette-like appearance.
In many Rosaceous species strawberries included, terminal meristems borne on short shoots are more prone to receiving the floral induction stimulus and initiating flowers than meristems borne on vigorously growing long shoots (Hytönen et al., 2004; Heide and Sønsteby, 2007; Wilkie et al., 2008; Sønsteby and Heide, 2019). Therefore, the balance between short and long shoots defines the yield potential and affects the choice and expenses of cultural practices, such as pruning or training.

Molecular studies in F. vesca (Koskela et al., 2012; Rantanen et al., 2015) and cultivated strawberry Fragaria $\times$ ananassa Duch. (Koskela et al., 2016) have highlighted the role of TERMINAL FLOWER1 (TFL1) as a floral repressor. In F. vesca, photoperiodic pathway culminates in the regulation of SUPPRESSOR OF OVEREXPRESSION OF CONSTANS1 (FvSOC1), which activates FvTFL1 in long days (LDs), and flower induction occurs in SDs after gradual downregulation of FvSOC1 and FvTFL1 (Koskela et al., 2012; Mouhu et al., 2013; Rantanen et al., 2015; Kurokura et al., 2017). However, this photoperiodic pathway regulates flowering only within a narrow temperature range between 13 and $20^{\circ} \mathrm{C}$ (Rantanen et al., 2015). Lower temperatures repress FvTFL1 and induce flowering independently of photoperiod, while higher temperatures activate FvTFL1 and inhibit flowering regardless of the photoperiod (Rantanen et al., 2015).

The function of TFL1 in Rosaceous species is conserved. Silencing or knocking out TFL1 homologs in apple and pear (Pyrus communis L.) result in reduced juvenility, precocious flowering, and even perpetual flowering (Kotoda et al., 2006; Flachowsky et al., 2012; Freiman et al., 2012; Charrier et al., 2019). Likewise, loss of function of TFL1 homologs in roses (Rosa spp.) and F. vesca lead to perpetual flowering (Iwata et al., 2012; Koskela et al., 2012; Bai et al., 2021). The seasonal expression pattern of TFL1 is highly connected to the yearly growth cycle in apple, F. vesca, and roses, as TFL1 is activated in the SAM during the vegetative growth phase and downregulated before the floral induction to allow flower initiation (Mimida et al., 2011; Iwata et al., 2012; Kurokura et al., 2013; Koskela et al., 2017). With such a conserved function and expression patterns across rosaceous species, it is reasonable to expect that results from studies on TFL1 in one species are applicable to other species.

Regulation of AXB fate in Rosaceae has been mainly studied at the phenotype level, perhaps because the molecular processes taking place within the well-protected AXB are difficult to examine. However, recent reports in $F$. vesca demonstrated that stolon development requires GIBBERELLIN 20-OXIDASE4 (FvGA20ox4) that is activated within the AXBs under LD conditions via an FvSOC1-dependent photoperiodic pathway at $18^{\circ} \mathrm{C}$ (Mouhu et al., 2013; Tenreira et al., 2017; Andrés et al., 2021). Higher temperature of $22^{\circ} \mathrm{C}$ upregulates FvGA20ox4 independently of $F v S O C 1$, whereas at cooler temperature $\left(11^{\circ} \mathrm{C}\right)$, FvGA20ox4 is de-activated in both $\mathrm{SD}$ and $\mathrm{LD}$ conditions (Andrés et al., 2021). Cool temperatures, as well as SDs at $18^{\circ} \mathrm{C}$, promote $\mathrm{BC}$ development instead of stolons in the seasonal flowering F. vesca, and although the same environmental cues induce flowering, these two processes can occur independently (Andrés et al., 2021). However, the fate of the 
youngest AXB located immediately below the SAM is directly dependent on the vegetative/generative status of the SAM; if the SAM is induced to flower, the youngest AXB develops a branch crown to continue the growth of the plant in a sympodial fashion (Sugiyama et al., 2004; Andrés et al., 2021).

Studying phenotypic and genetic variation present in related species is based on the rationale that species sampled from diverse environments have faced different selection pressures, leading to evolution of local adaptation and phenotypical differences. We took advantage of this rationale to study environmental responses in wild diploid species of Fragaria originating from a wide geographical range. Our collection of wild diploid Fragaria included accessions native to high altitude (F. bucharica and F. nubicola Lindl. from the Himalayas) as well as accessions endemic to less harsh environments (F. iinumae Makino growing in the Japanese archipelago and F. nilgerrensis and F. pentaphylla Losinsk. from South East Asia). In addition, we included our Finnish reference accession of $F$. vesca that is adapted to temperate climate, $F$. viridis Weston from Central Europe and F. chinensis Losinsk. from North Western China. We analyzed the collection in terms of flowering habits and vegetative development and selected F. bucharica and F. nilgerrensis for detailed analysis together with F. vesca. Our results indicated that TFL1 homologs are key integrators of temperature and photoperiodic cues in these three species and that altered regulation of TFL1 may explain variation in their flowering habits. We also found that the activities of GA200x4 homologs correlated with AXB fate in the studied species.

\section{MATERIALS AND METHODS}

\section{Plant Material}

Fourteen accessions of seven wild diploid strawberry species (Supplementary Table 1), provided by the Professor Staudt Collection maintained by Hansabred GmbH Co. KG in Dresden, Germany, were included in initial screening of flowering responses. If there is any interest on the plant material, the corresponding author or Hansabred ${ }^{1}$ should be contacted. Other experiments included $F$. nilgerrensis accession \#1, F. bucharica accession \#1, and seasonal flowering $F$. vesca accession FIN56 (PI551792, National Clonal Germplasm Repository, Corvallis, OR, United States) as a control. All plant materials used in this study were propagated from stolon cuttings in a greenhouse. Plants were first grown on jiffy pellets (Jiffy Products International) for 3 weeks and then transplanted to $8 \mathrm{~cm} \times 8 \mathrm{~cm}$ pots with fertilized peat (Kekkilä, Finland). Liquid fertilizer (Kekkilä, N-P-K: 17-4-25, Finland) was given to the plants biweekly.

\section{Treatments and Observations}

Plants were grown in a greenhouse under $18 \mathrm{~h} \mathrm{LD}$ at $18^{\circ} \mathrm{C}$ for 4 weeks before the experiments started. In the greenhouse,

${ }^{1}$ www.hansabred.org plants were illuminated by natural light, and high-pressure sodium lamps (Airam $400 \mathrm{~W}$, Kerava, Finland) at a photosynthetic photon flux density (PPFD) of $120 \mu \mathrm{molm}^{-2} \mathrm{~s}^{-1}$ were used to extend the day length. Temperature $\left(11\right.$ and $\left.18^{\circ} \mathrm{C}\right)$ and photoperiod (12-h SD and 18-h LD) treatments were carried out in growth chambers equipped with LED lamps (AP67, Valoya, Finland; $200 \mu \mathrm{mol} \mathrm{m}{ }^{-2} \mathrm{~s}^{-1}$ of PPFD). The experimental details are described in the figure legends. During the experiments, the number of leaves, stolons, and BCs were observed weekly, and stolons were removed after recording. For flowering time observations, both the numbers of leaves from the primary leaf rosette and the number of days when the first fully open flower emerged were recorded. In this study, the BC number referred to the number of axillary leaf rosettes excluding the sympodial $\mathrm{BC}$ arising from the topmost axil upon floral initiation.

\section{Gene Expression Data}

Shoot apex samples were collected for gene expression analysis. Total RNA was extracted as described by Koskela et al. (2012) and treated with rDNase (Macherey-Nagel GmbH, Düren, Germany) according to the manufacturer's instructions. cDNA was synthesized from $500 \mathrm{ng}$ of total RNA using ProtoScript II Reverse Transcriptase according to manufacturer's instructions (New England Biolabs). SYBR Green I master mix was used for quantitative real-time PCR (qRT-PCR) in a total reaction volume of $10 \mu \mathrm{l}$ and analyzed by LightCycler 480 instrument (Roche) as described by Koskela et al. (2012). Four biological replicates and three technical replicates were used for qRT-PCR analysis using the primers listed in Supplementary Table 2. Relative expression levels were calculated by $\Delta \Delta \mathrm{Ct}$ method as described by Pfaffl (2007). FvMSI1 (MULTICOPY SUPPRESSOR OF IRA1) was used as a reference gene for normalization.

\section{Statistical Analyses}

Either logistic regression or ANOVA was conducted to test the main factors, and pairwise comparisons were performed by Tukey HSD. The statistical analyses were done using R.4.1.0 (R Core Team, 2021), the stats (v4.1.0; R Core Team, 2021), and the DescTools (v0.99.42; Andri et al., 2021) packages.

\section{RESULTS}

\section{Flowering Time Variation Among Diploid Strawberry Species}

To get the first insights into flowering responses to environmental cues in different diploid strawberry species, 14 accessions of seven species were subjected to $18 \mathrm{~h} \mathrm{LD}$ and $12 \mathrm{~h}$ SD treatments at $11^{\circ} \mathrm{C}$ for 6 weeks, followed by flowering observations in LDs at $18^{\circ} \mathrm{C}$. Eleven accessions showed clear flowering response to at least one of the treatments (Figure 1A). All the plants of two F. bucharica and three F. viridis accessions flowered after both LD and SD treatments, showing a similar photoperiodindependent flowering response to cool temperature as SD genotypes of F. vesca (Heide and Sønsteby, 2007; Rantanen 


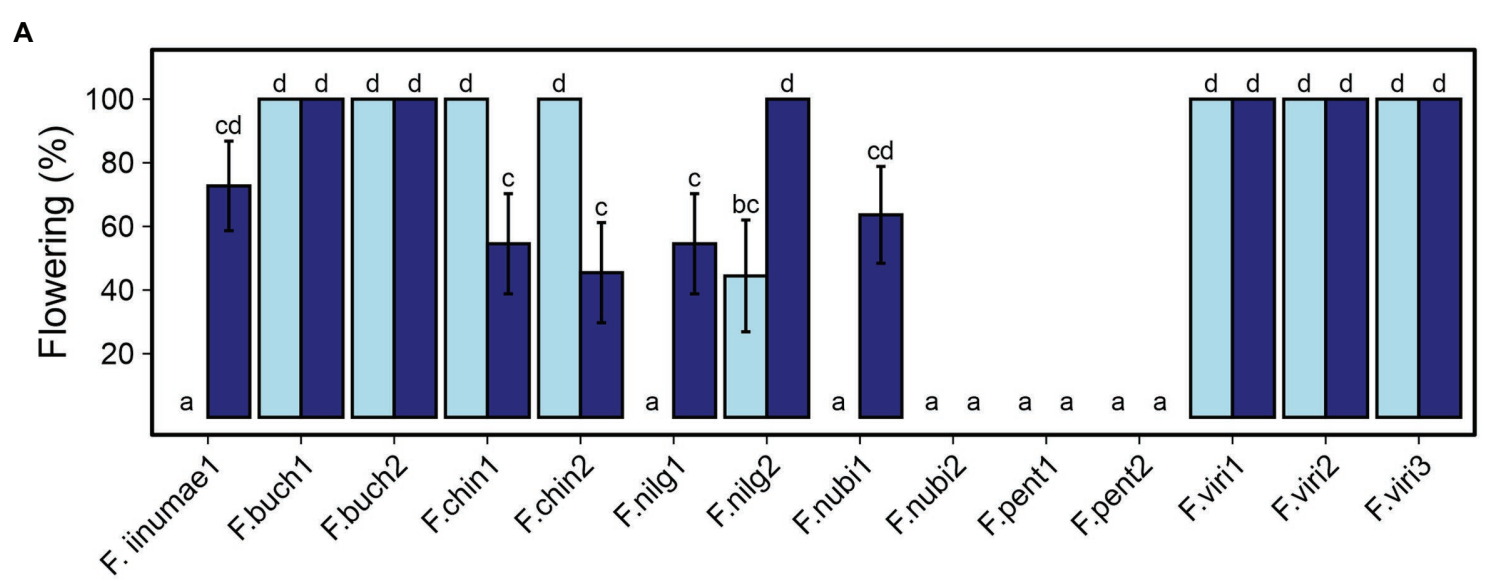

B

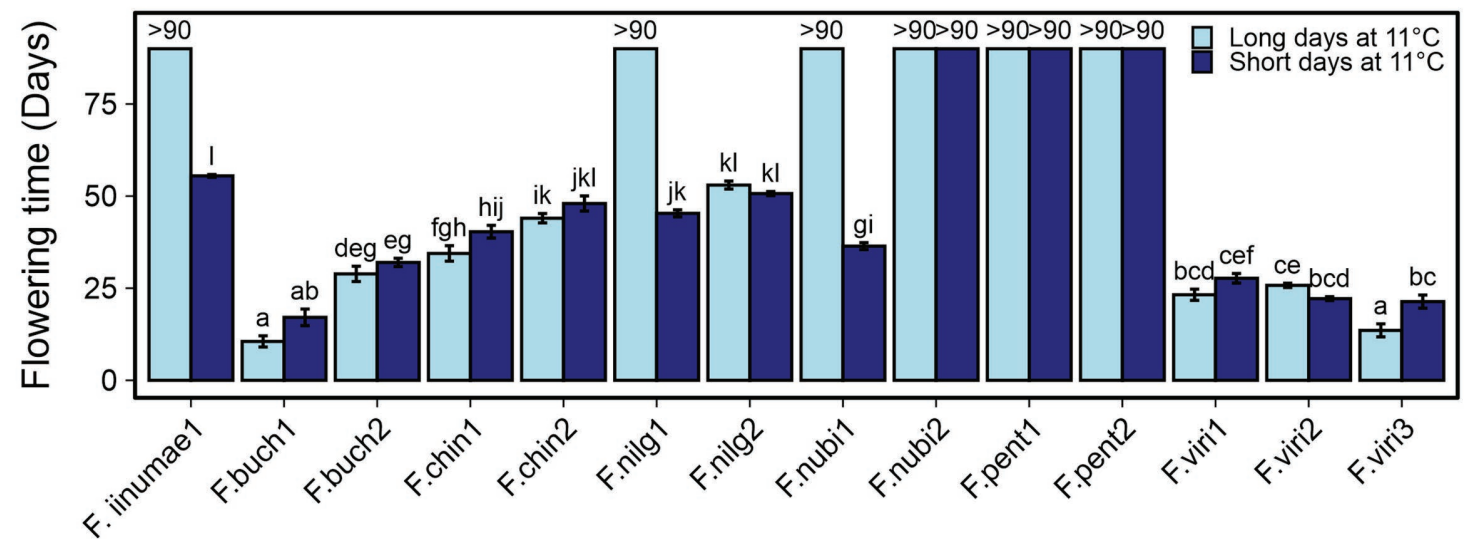

FIGURE 1 | Flowering responses of diploid species to $12 \mathrm{~h}$ short day (SD) and $18 \mathrm{~h}$ long day (LD) treatments at $11^{\circ} \mathrm{C}$. Percentage of flowering plants (A) and days to the first open flower (B). Stolon-propagated plants were grown under 18- or 12 -h photoperiod at $11^{\circ} \mathrm{C}$ for 6 weeks followed by LDs $(18-\mathrm{h})$ at $18^{\circ} \mathrm{C}$. Flowering was recorded every other day, starting after the treatments. Error bars represent the SEM $(n=7-11)$, and different letters indicate significant differences calculated by ANOVA and Tukey's test $(p<0.05)$. For accessions that remained vegetative, the number of days recorded is shown $(>90)$.

et al., 2015). In the two F. chinensis accessions, floral induction took place in all the LD-grown plants, whereas only roughly half of the plants were induced under SD conditions. Opposite photoperiodic response was found in two accessions of F. nilgerrensis, in which SDs resulted in a higher percentage of flowering plants. In F. nilgerrensis \#1, as well as in F. iinumae $\# 1$ and F. nubicola \#1, flowering occurred only after the SD treatment (Figure 1A). Finally, flowering was not observed in F. nubicola \#2 and the two F. pentaphylla accessions under either photoperiod. There were also significant differences in flowering time between the species and accessions (Figure 1B). Accessions of F. bucharica and F. viridis flowered rapidly after the temperature treatment independently of photoperiod, except for $F$. viridis \#3 in which LDs promoted flowering, while $F$. iinumae and F. nilgerrensis accessions flowered significantly later.

Because we were not able to induce F. nubicola \#2 and the two F. pentaphylla accessions to flower under SDs or LDs at $11^{\circ} \mathrm{C}$, we tested if a prolonged cold treatment could induce them to flower. After 1 months in $12 \mathrm{~h} \mathrm{SD}$ at $14^{\circ} \mathrm{C}-15^{\circ} \mathrm{C}$, plants were moved to $5^{\circ} \mathrm{C}-6^{\circ} \mathrm{C}$ for about 4 months. This treatment induced flowering in all the plants of both F. pentaphylla accessions that did not flower after $11^{\circ} \mathrm{C}$ treatment (Supplementary Table 3). However, F. nubicola \#2 did not flower, and inductive conditions for this accession remained an enigma. Furthermore, F. iinumae \#1 did not flower, although it flowered in a previous experiment. In conclusion, the screening experiment with 14 Fragaria accessions revealed an interesting diversity of flowering responses.

\section{The Effect of Photoperiod on Flowering Time and AXB Fate at $18^{\circ} \mathrm{C}$}

Next, we studied flowering responses of two accessions in more detail and compared them with the seasonal flowering $F$. vesca reference genotype, FIN56. We selected F. bucharica \#1 because it flowered first in the initial screening experiment and $F$. nilgerrensis \#1 because it flowered late and had a clear photoperiodic response at $11^{\circ} \mathrm{C}$ (Figure 1; the rest of the experiments included only one genotype per accession and 
therefore F. bucharica \#1 and F. nilgerrensis \#1 are referred to as $F$. bucharica and F. nilgerrensis from here onward). First, we decided to subject the three species to LDs or SDs at $18^{\circ} \mathrm{C}$, because the phenotypical responses and gene expression profiles in $F$. vesca are well characterized under these conditions.

A 6-week SD treatment at $18^{\circ} \mathrm{C}$ induced early flowering in both F. vesca and F. bucharica (Figure 2). However, also LD-grown control plants of both species flowered, but significantly later than SD-grown plants, and longer delay was observed in F. vesca. In contrast, F. nilgerrensis did not flower under either photoperiod at $18^{\circ} \mathrm{C}$.

Fragaria vesca ceased stolon development after 3 weeks of SDs. The final number of stolons in F. vesca at the end of the experiment was significantly higher in LDs than in SDs (Figure 3A). Fragaria bucharica did not stop stolon development under either photoperiod, although LDs slightly promoted stolon development also in this species (Figure 3A). Stolon development in F. nilgerrensis ceased after 5 weeks in SDs at $18^{\circ} \mathrm{C}$, whereas LDs promoted stolon development until the end of the experiment (Figure 3A).

The three species behaved very differently in terms of $\mathrm{BC}$ development at $18^{\circ} \mathrm{C}$. In F. vesca, BC development was observed in both photoperiods, with SDs promoting BC development

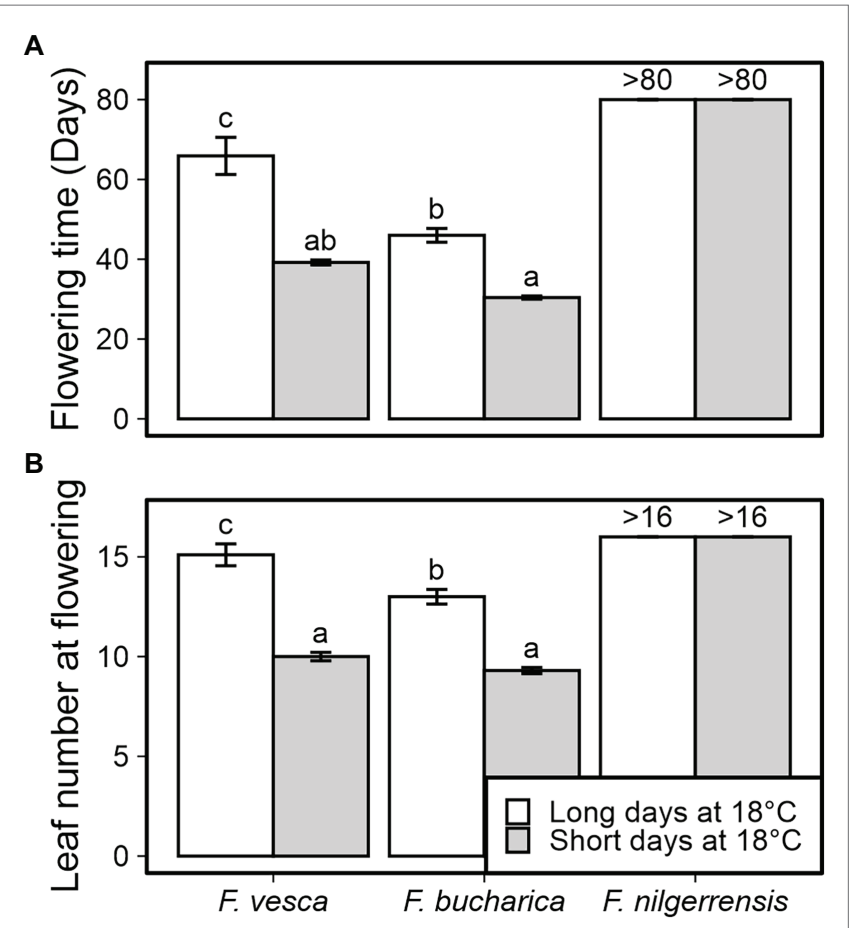

FIGURE 2 | Flowering time in three diploid strawberry species grown in SDs or LDs at $18^{\circ} \mathrm{C}$. Number of days (A) and number of leaves developed (B) until the first flower opened. Stolon-propagated plants were grown in LDs (18-h) or SDs (12-h) at $18^{\circ} \mathrm{C}$ for 6 weeks followed by LDs (18-h) at $18^{\circ} \mathrm{C}$. Flowering time was recorded every other day and leaf number was scored at flowering time. Error bars represent the SEM $(n=10)$, and different letters indicate significant differences calculated by ANOVA and Tukey's test $(p<0.05)$. For plants that remained vegetative, the number of days recorded $(>80)$ or the number of leaves observed $(>16)$ is shown.
(Figure 3B). Intriguingly, F. bucharica did not develop any BCs under either photoperiod. In F. nilgerrensis, 6 weeks of $\mathrm{SDs}$ at $18^{\circ} \mathrm{C}$ strongly promoted $\mathrm{BC}$ development whereas the LD-grown F. nilgerrensis did not develop any BCs (Figure 3B). Taken together, all species responded to photoperiod, but showed contrasting responses; in $F$. vesca, photoperiod affected both flowering and AXB fate, F. bucharica showed SD promotion of flowering but no strong photoperiodic effects on $\mathrm{AXB}$ fate, while in $F$. nilgerrensis, photoperiod affected only AXB fate.

\section{Altered Expression of Key Genes Is Associated With Different Phenotypical Responses at $18^{\circ} \mathrm{C}$}

To gain an initial idea of how the photoperiodic pathway functions in F. bucharica and F. nilgerrensis, we decided to study the expression of SOC1, TFL1, and GA20ox4 in these species in comparison to $F$. vesca. The SOC1 genes had a very clear photoperiodic response in all three species and the expression patterns were very similar. SOC1 remained active in $\mathrm{LDs}$ at $18^{\circ} \mathrm{C}$, whereas SDs downregulated the gene (Figure $4 \mathrm{~A}$ ), suggesting that the photoperiodic regulation of SOC1 at $18^{\circ} \mathrm{C}$ is conserved in these diploid species.

Earlier experiments in F. vesca have shown that FvTFL1 is gradually de-activated after transferring the plants to $\mathrm{SD}$ conditions (Koskela et al., 2012). In our current experiment, TFL1 expression dropped to low levels in both $F$. vesca and F. bucharica within 2 weeks under SD conditions, and the expression further declined until week 4 (Figure 4B). In $F$. nilgerrensis, TFL1 expression in SDs remained at higher level than in the other two species, although there was still a clear photoperiodic effect, indicating that the high activity of TFL1 may inhibit floral induction in the experimental conditions used. Moreover, regulation of TFL1 in F. nilgerrensis (FnTFL1) does not follow the expression pattern of SOC1, implying that FnTFL1 is regulated by factor(s) other than the SOC1-dependent pathway. The analysis of available $F$. vesca and $F$. nilgerrensis genomic sequences showed extensive variation in putative regulatory regions of TFL1 (Supplementary Figure 1; Edger et al., 2017; Zhang et al., 2020), which may explain differential regulation of TFL1 in these species.

GIBBERELLIN 20-OXIDASE4 was rapidly downregulated upon exposure to SDs in both $F$. vesca and $F$. nilgerrensis (Figure 4C). Concurring with the stolon phenotype, we found that the expression of GA200x4 in F. bucharica remained at a high level in LDs and SDs at $18^{\circ} \mathrm{C}$. The finding in F. bucharica suggests that in this species the regulation of GA20ox4 is uncoupled from the expression of SOC1, leading to continuous and photoperiod-independent development of stolons at $18^{\circ} \mathrm{C}$.

\section{Three Diploid Fragaria Species Exhibit Distinct Phenotypic Responses at $11^{\circ} \mathrm{C}$}

Next, we wanted to study the phenotypical responses of the three Fragaria species at $11^{\circ} \mathrm{C}$ at a more detailed level. We repeated the photoperiodic experiment at $11^{\circ} \mathrm{C}$ and observed flowering and AXB fates. It has been earlier shown in $F$. vesca that cool temperature induces flowering independently of 
A
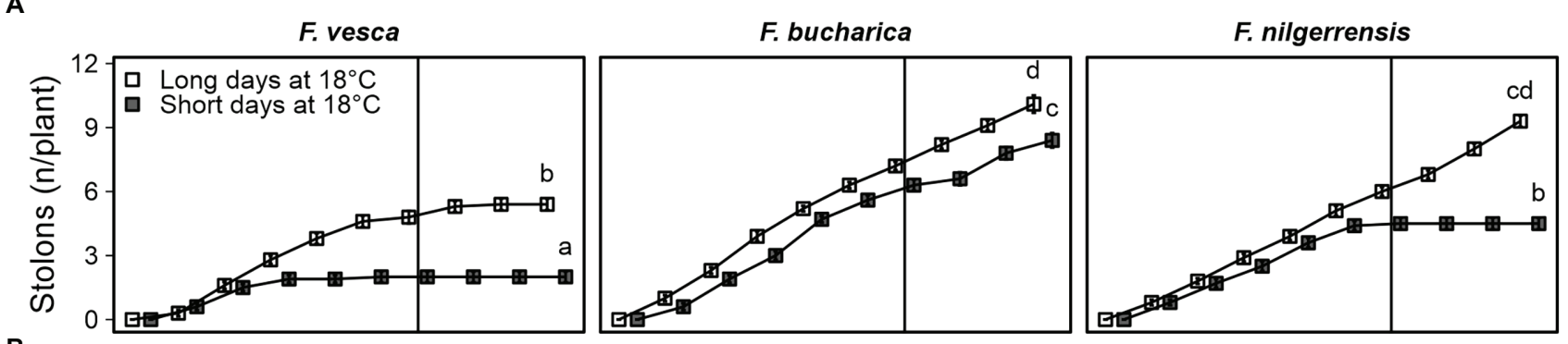

B
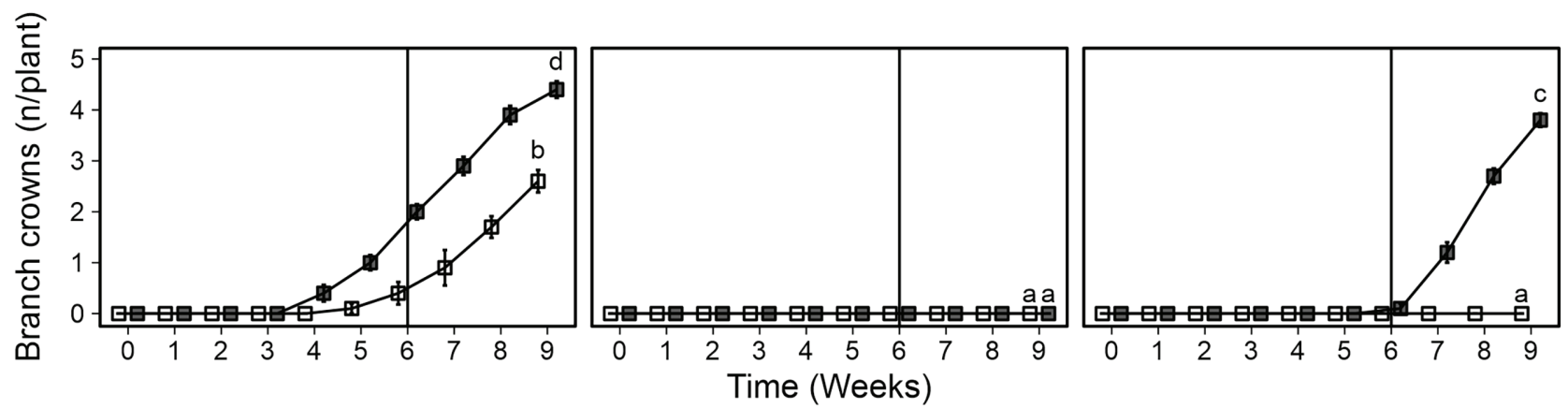

FIGURE 3 | Axillary bud fate of three diploid strawberry species grown in SDs or LDs at $18^{\circ} \mathrm{C}$. Number of stolons (A) and branch crowns (B) per plant. Stolonpropagated plants were grown in LDs (18-h) or SDs (12-h) at $18^{\circ} \mathrm{C}$ for 6 weeks followed by LDs (18-h) at $18^{\circ} \mathrm{C}$. Number of stolons and branch crowns was recorded weekly until week 9 . Error bars represent the SEM $(n=10)$ and different letters indicate significant differences calculated by ANOVA and Tukey's test $(p<0.05)$.

photoperiod (Heide and Sønsteby, 2007; Rantanen et al., 2015; Andrés et al., 2021). We found similar photoperiod-independent response in both $F$. vesca and F. bucharica after 6 weeks at $11^{\circ} \mathrm{C}$ with significantly later flowering in F. bucharica, while the control plants grown under $\mathrm{LD}$ conditions at $18^{\circ} \mathrm{C}$ remained vegetative until the end of the experiment (Figure 5). By contrast, no flowering plants were observed in F. nilgerrensis in this experiment, and only $50 \%$ of plants flowered in the initial screening under SDs at $11^{\circ} \mathrm{C}$, indicating that a 6-week treatment at $11^{\circ} \mathrm{C}$ is not sufficient for complete floral induction in this species.

We found differences in the environmental regulation on AXB fate among the three diploid strawberry species. Overall, in all species, the control plants developed stolons continuously at a relatively stable speed throughout the experiment (Figure 6A). Cool temperature strongly suppressed stolon development in F. vesca and stolon development did not resume after returning the plants to $18^{\circ} \mathrm{C}$. Similarly to $F$. vesca, stolon development ceased in F. bucharica after 3 weeks at $11^{\circ} \mathrm{C}$ under both $\mathrm{LD}$ and $\mathrm{SD}$ conditions, but in contrast to $F$. vesca, F. bucharica started stolon development again 2 weeks after the treatments. In F. nilgerrensis, stolon development was markedly slowed down at cool temperature compared with the control plants, but no clear cessation of stolon development was observed. On the other hand, $F$. bucharica and F. nilgerrensis plants subjected to LDs at $11^{\circ} \mathrm{C}$ had significantly more stolons on week 9 than plants grown in SDs. In $F$. vesca, such a photoperiodic effect was not observed.
The three Fragaria species differed in terms of branch crown development. Fragaria vesca started to develop BCs independently of the photoperiod immediately after the 6-week period at $11^{\circ} \mathrm{C}$ (Figure 6B). On the contrary, F. bucharica developed very few $\mathrm{BCs}$ after the photoperiodic treatments at $11^{\circ} \mathrm{C}$, although it behaved similarly to $F$. vesca in terms of stolon development and all the plants flowered. F. nilgerrensis started to develop BCs after the photoperiodic treatments at $11^{\circ} \mathrm{C}$ with SDs promoting $\mathrm{BC}$ development (Figure 6B). It is noteworthy that $\mathrm{BC}$ development in F. nilgerrensis occurred independent of floral induction, as none of the plants flowered. The control plants grown continuously under LDs at $18^{\circ} \mathrm{C}$ did not develop BCs in these species. Taken together, our data indicate that AXB fate in the three studied Fragaria species is controlled by different mechanisms; in F. vesca, cool temperature of $11^{\circ} \mathrm{C}$ promotes $\mathrm{BC}$ development and suppresses stolon development independently of photoperiod, while AXB fate in F. nilgerrensis is clearly dependent on photoperiod. Moreover, BC development in F. bucharica appears to be endogenously regulated, as neither photoperiod nor temperature affected BC development.

\section{The Expression of Key Genes Correlates With Flowering and AXB Fate at $11^{\circ} \mathrm{C}$}

Next, we wanted to examine whether the phenotypical differences observed in the three Fragaria species at $11^{\circ} \mathrm{C}$ could be explained by altered expression of key genes. Earlier studies in F. vesca suggest that $F v S O C 1$ is activated by $\mathrm{LDs}$ at $10^{\circ} \mathrm{C}$, albeit to a 


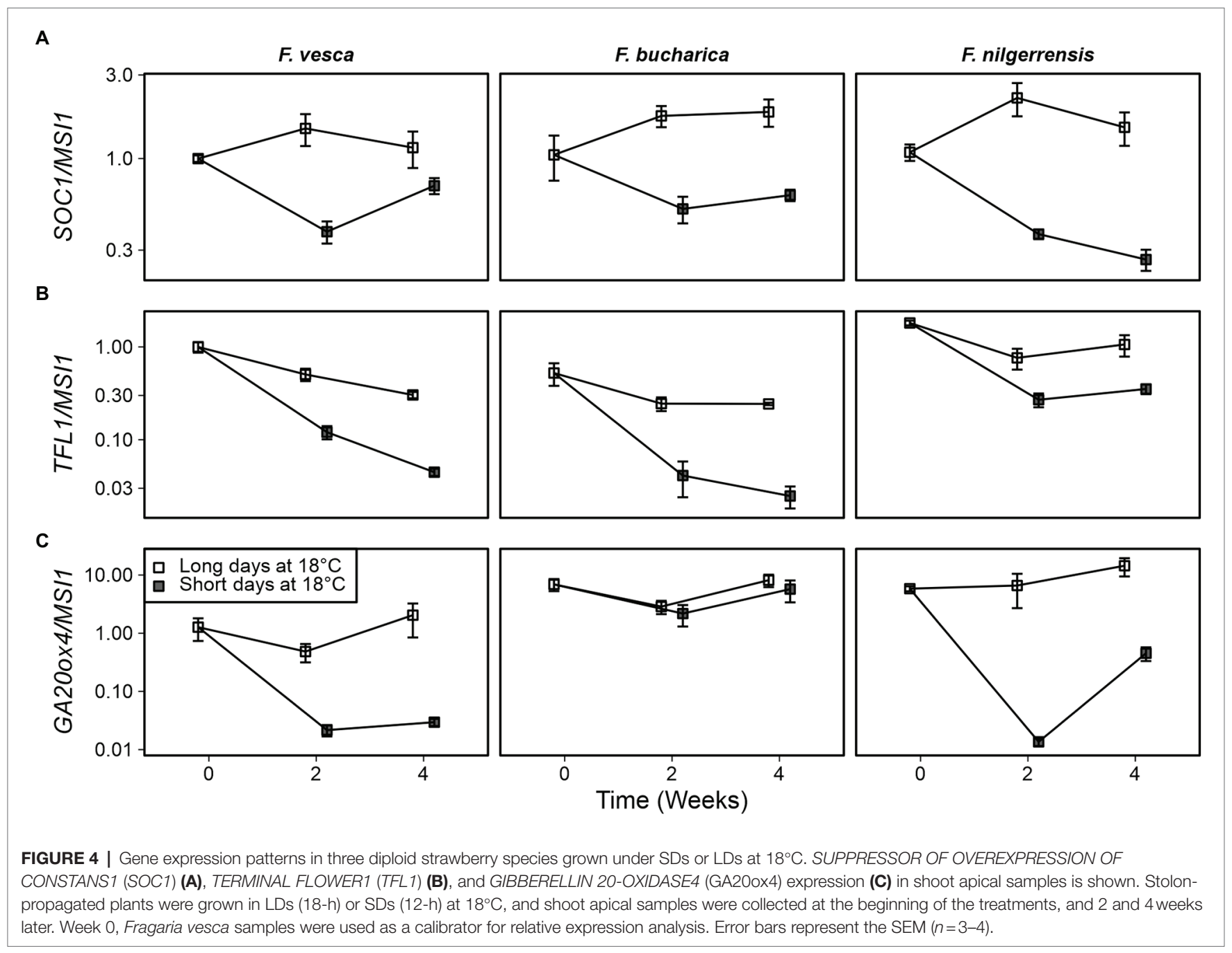

lesser extent than at higher temperatures (Rantanen et al., 2015). In our current experiments at $11^{\circ} \mathrm{C}$, we saw clear SD-dependent downregulation of SOC1 in F. vesca, as well as in F. bucharica (Figure 7A; Supplementary Figure 2). In F. nilgerrensis, the pattern of SOC1 expression was not very clear, although by week 6 the level of SOC1 mRNA was lower in SDs than in LDs.

As shown earlier by Rantanen et al. (2015), FvTFL1 in F. vesca is de-activated independently of photoperiod at $11^{\circ} \mathrm{C}$. TFL1 was gradually downregulated at $11^{\circ} \mathrm{C}$ also in our current experiments in both F. vesca and F. bucharica, and F. bucharica showed stronger downregulation of TFL1 than $F$. vesca (Figure 7B; Supplementary Figure 2). On the contrary, downregulation of TFL1 in F. nilgerrensis occurred slower, and at week 6, TFL1 expression was still higher in F. nilgerrensis than in the other species.

We also analyzed the expression of GA200x4. The effect of $11^{\circ} \mathrm{C}$ treatment on GA20ox4 activity was very clear for all the species. In F. vesca and F. bucharica, the expression level was much lower after 6 weeks at $11^{\circ} \mathrm{C}$ than in the beginning of the experiment, correlating with the lack of stolon development in these two species (Figure 7C). Results in these species also showed that this downregulation occurred gradually in both photoperiods (Figure 7C; Supplementary Figure 2). By contrast, although GA20ox4 expression in F. nilgerrensis also declined gradually, it was clearly more downregulated in SDs than in LDs from week 2 onward. The difference between photoperiods was even more evident by week 6 , being in line with the effect of photoperiod on stolon development in this species.

\section{DISCUSSION}

The molecular mechanisms regulating floral induction and $\mathrm{AXB}$ fate as a response to environmental conditions are starting to emerge in the diploid model species F. vesca (Hytönen and Kurokura, 2020; Andrés et al., 2021). To gain a broader view on the diversity of regulation of flowering and AXB fate within the Fragaria genus, we studied these responses in a panel of wild diploid strawberry species with diverse geographical origins ranging from Asia to Europe. Some of these species inhabit very local habitats while some are widely spread around the Northern Hemisphere (Liston 


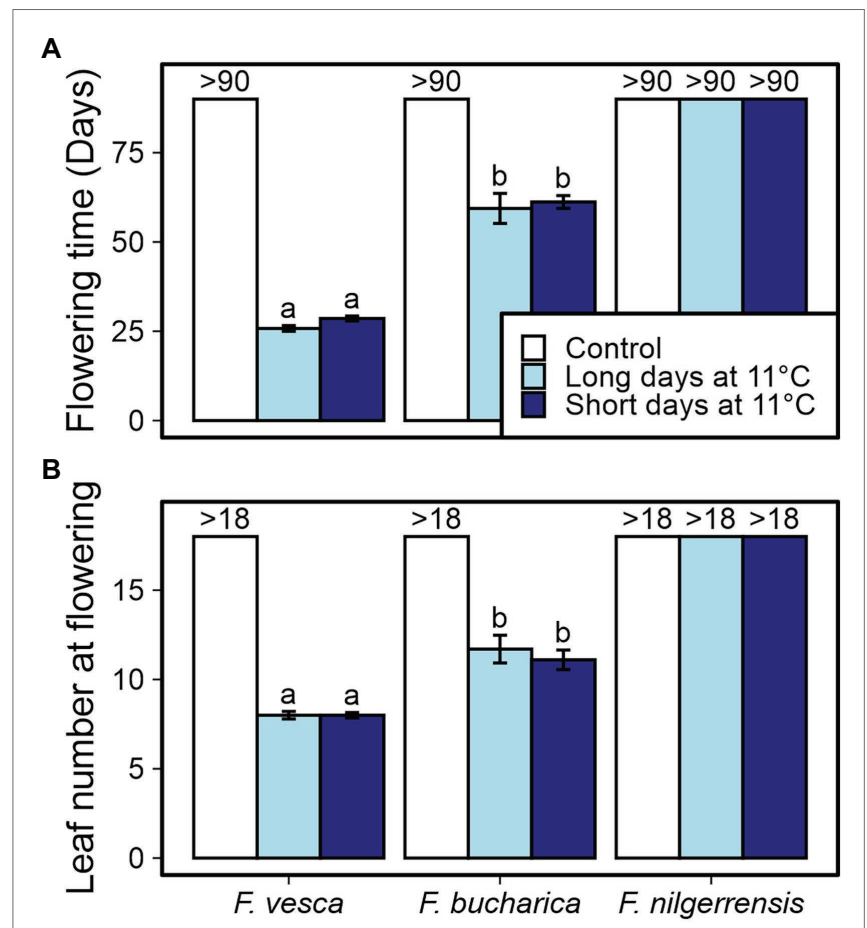

FIGURE 5 | Flowering characterization of three diploid strawberry species grown under SDs or LDs at $11^{\circ} \mathrm{C}$. Number of days (A) and number of leaves developed (B) until the first flower opened. Stolon-propagated plants were grown in LDs (18-h) or SDs (12-h) at $11^{\circ} \mathrm{C}$ for 6 weeks followed by LDs (18-h) at $18^{\circ} \mathrm{C}$. Control plants were grown in LDs $(18-h)$ at $18^{\circ} \mathrm{C}$ from the beginning of the experiment. Flowering time was recorded every other day, starting after the treatments. Error bars represent the SEM $(n=10)$ and different letters indicate significant differences calculated by ANOVA and Tukey's test $(p<0.05)$. For plants that remained vegetative, the number of days recorded $(>90)$ or the number of leaves observed $(>18)$ is shown.

et al., 2014). Here, we characterized the flowering habits of 14 accessions from seven wild diploid strawberry species under controlled environmental conditions. Based on their diverse flowering responses, we further selected two representative species, F. bucharica and F. nilgerrensis, and analyzed their flowering habits, AXB fate, and expression of key genes related to these biological processes in comparison to the reference model species $F$. vesca.

\section{Diversity of Flowering Responses in Diploid Fragaria Species}

We discovered a diversity of flowering responses in our collection of diploid Fragaria species. F. bucharica and F. viridis were clearly photoperiod-insensitive at cool temperature and flowered rapidly after both $\mathrm{SD}$ and $\mathrm{LD}$ treatments at $11^{\circ} \mathrm{C}$, similarly to the model species F. vesca (Figure 1; Rantanen et al., 2015). These results were in line with the earlier field observations on facile floral induction in these species; F. bucharica flowered twice during the growing season when grown in Germany (Staudt, 2006), and F. viridis was described as "remontant" under field conditions in South East England (Sargent et al., 2004), as also observed in the Professor Staudt Collection in Germany (data not shown). In contrast to these species, the promoting effect of SDs was obvious in F. iinumae, F. nilgerrensis, and F. nubicola \#1, while LDs advanced flowering in F. chinensis at $11^{\circ} \mathrm{C}$, a response that has not been previously described in Fragaria (Figure 1). Finally, F. pentaphylla and F. nubicola \#2 did not flower at all after $11^{\circ} \mathrm{C}$ treatments. The diverse responses observed in our collection warrant further investigation to uncover mechanisms controlling flowering time variation in these species.

In general, diploid strawberries flower in their original habitats in spring/summer after overwintering (Staudt et al., 2003; Staudt, 2005, 2006, 2009), and all tested accessions of F. iinumae, F. nilgerrensis, F. nipponica, F. nubicola, F. pentaphylla, F. viridis, and F. vesca flowered and produced fruits after overwintering in the field in South East England (Sargent et al., 2004). Likewise, a long-term exposure to $5^{\circ} \mathrm{C}-6^{\circ} \mathrm{C}$ in a greenhouse without supplemental light promoted flowering in the majority of the accessions we tested, excluding F. iinumae and F. nubicola \#2 (Supplementary Table 3). In contrast, Bors and Sullivan (2005) reported that a 2 -month period at constant $-1{ }^{\circ} \mathrm{C}$ could not induce some accessions of $F$. nilgerrensis, F. nubicola, $F$. pentaphylla, and F. viridis to flower and an additional floral induction treatment under $10-\mathrm{h}$ SDs at $18 / 15^{\circ} \mathrm{C}$ (day/night) was necessary. As the experimental conditions, as well as the plant materials, differ between the studies (Sargent et al., 2004; Bors and Sullivan, 2005), direct comparisons are difficult. The contrasting results highlight the need for experimentation under controlled climate to uncover the exact environmental conditions required for floral induction in Fragaria species. Furthermore, observations in the Professor Staudt Collection indicate that plant age should also be considered (data not shown).

\section{Variation in TFL1 Regulation Correlates With Contrasting Flowering Habits in Three Diploid Fragaria Species}

TERMINAL FLOWER1 is a strong floral repressor in different Rosaceous species (Kotoda et al., 2006; Flachowsky et al., 2012; Freiman et al., 2012; Iwata et al., 2012; Koskela et al., 2012, 2016; Charrier et al., 2019). We found a clear association between FvTFL1 de-activation and flowering in F. vesca, corroborating the earlier findings by Rantanen et al. (2015), and a similar association was found in F. bucharica. In both species, SDs suppressed TFL1 and promoted flowering at $18^{\circ} \mathrm{C}$, whereas TFL1 downregulation and floral induction occurred independently of photoperiod at $11^{\circ} \mathrm{C}$ (Figures 2, 4B, 5, 7B). However, we were unable to induce flowering in F. nilgerrensis in $\mathrm{SDs}$ at $18^{\circ} \mathrm{C}$, and after 6-week treatments at $11^{\circ} \mathrm{C}$, flowering was observed only in some plants in one of the two experiments. As $F$. nilgerrensis TFL1 mRNA showed overall higher level, slower downregulation at $11^{\circ} \mathrm{C}$, and weak photoperiodic response at $18^{\circ} \mathrm{C}$ compared with other species, this species may require longer exposure to cool temperatures or photoperiods shorter than $12 \mathrm{~h}$ to downregulate TFL1 below the threshold level for flower induction. In consistence with this hypothesis, the species originates from low latitude area with relatively mild seasonal changes of temperature and photoperiod, where the period of flower-inductive conditions is longer than in the colder habitats of F. vesca and F. bucharica (Liston et al., 2014). However, 


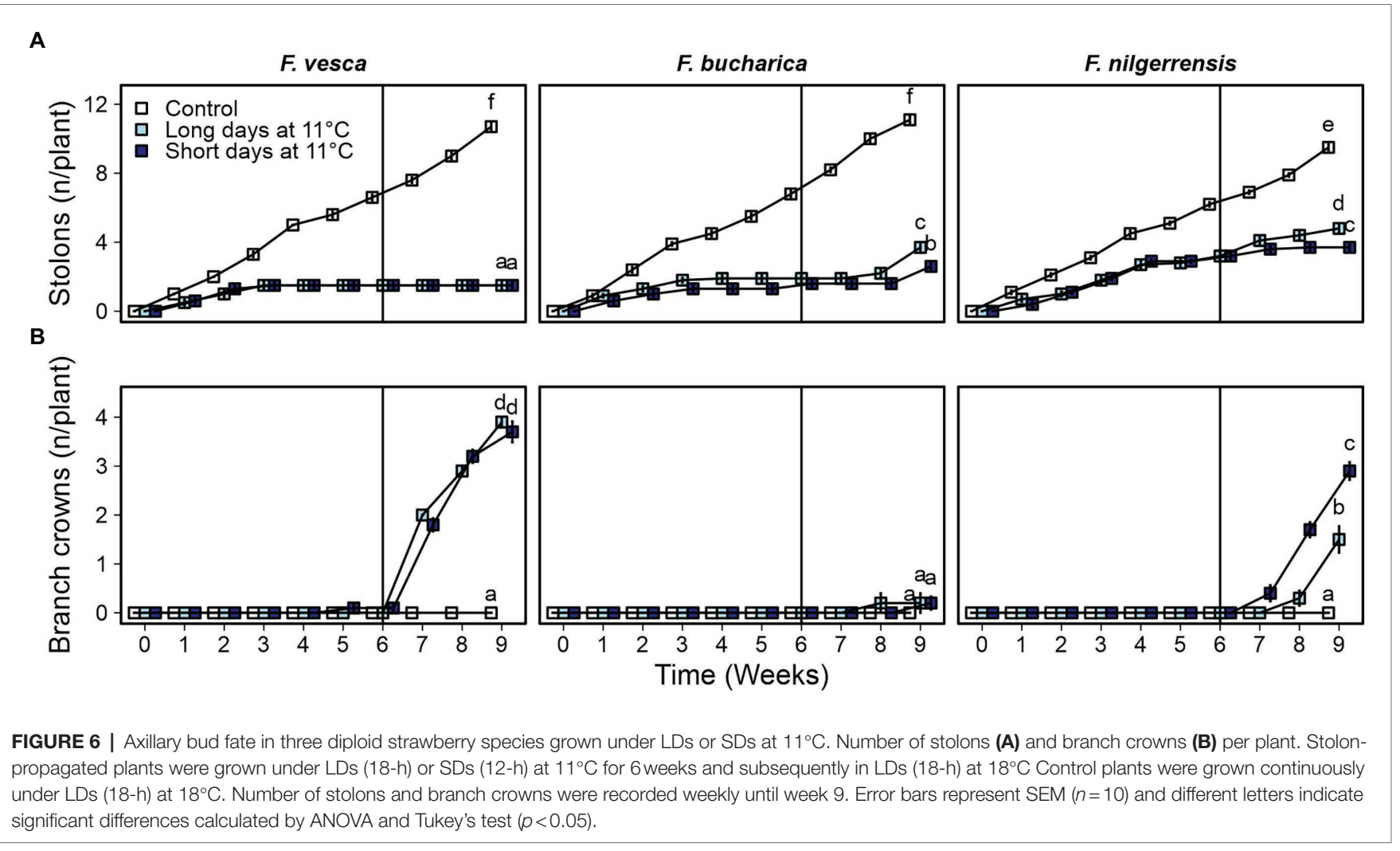

while the environmental conditions required for floral induction differ between the species, the role of TFL1 as a floral repressor appears to be conserved in F. vesca, F. bucharica, and F. nilgerrensis.

Earlier experiments in F. vesca identified $F v S O C 1$ as a major LD-activated promoter of FvTFL1 expression at $18^{\circ} \mathrm{C}$ (Mouhu et al., 2013). We observed LD-dependent activation of SOC1 expression at $18^{\circ} \mathrm{C}$ for $F$. vesca, F. bucharica, and F. nilgerrensis (Figure 4A), suggesting that the photoperiodic pathway upstream of SOC1 functions similarly in the three species. However, the downregulation of TFL1 expression coincided with that of SOC1 only in F. vesca and F. bucharica, as in F. nilgerrensis, FnTFL1 activity remained at a relatively high level under both photoperiods although FnSOC1 was strongly downregulated by SDs. This indicates an uncoupling of FnSOC1 and FnTFL1 expression patterns that is reminiscent of the events taking place in F. vesca at $23^{\circ} \mathrm{C}$; at this temperature, FvTFL1 is upregulated by an unknown pathway independently of FvSOC1 (Rantanen et al., 2015). It is possible that the temperature threshold for the activation of this unidentified pathway is lower in F. nilgerrensis than in F. vesca, leading to photoperiodand FnSOC1-independent upregulation of FnTFL1 already at $18^{\circ} \mathrm{C}$. Finally, at $11^{\circ} \mathrm{C}$, downregulation of TFL1 was not clearly associated with changes in SOC1 expression level in any of the three species, as previously reported in F. vesca (Rantanen et al., 2015).

In conclusion, TFL1 is a key integrator of environmental signals in the three studied diploid strawberry species, and variation in the downregulation of TFL1 may explain the observed differences in their photoperiodic and temperature responses. Further studies are needed to explore what are the molecular mechanisms controlling variation in TFL1 regulation.

\section{GA200x4 Promotes Stolon Development in the Three Fragaria Species}

Although the regulation of AXB fate in F. vesca has received attention in the recent years (Tenreira et al., 2017; Caruana et al., 2018; Li et al., 2018; Qiu et al., 2019; Andrés et al., 2021), AXB fate regulation has remained unexplored in other wild Fragaria species. We found that, in line with previous studies in F. vesca (Mouhu et al., 2013); SDs at $18^{\circ} \mathrm{C}$ completely inhibited stolon development in $F$. vesca and $F$. nilgerrensis after 3 and 6 weeks of treatments, respectively. However, stolon development of $F$. bucharica was reduced only slightly under SDs (Figure 3B). In $F$. vesca, this photoperiodic response is mediated via FvSOC1 that promotes stolon formation in LDs by upregulating FvGA20ox4 in AXBs, and the downregulation of these genes stops stolon formation (Andrés et al., 2021). In our current experiment, GA20ox4 expression was in line with that of SOC1 in F. vesca and F. nilgerrensis at $18^{\circ} \mathrm{C}$, but not in $F$. bucharica that exhibited clear photoperiodic regulation of SOC1 but barely noticeable differences in GA20ox4 expression (Figure 4). Andrés et al. (2021) found that, at $23^{\circ} \mathrm{C}, \mathrm{Fv} G A 200 \times 4$ expression is promoted by an unknown factor in SD-grown $F$. vesca plants, in spite of downregulation of FvSOC1. Perhaps the same factor upregulated GA20ox4 at $18^{\circ} \mathrm{C}$ in SD-grown F. bucharica plants in the current experiment. 


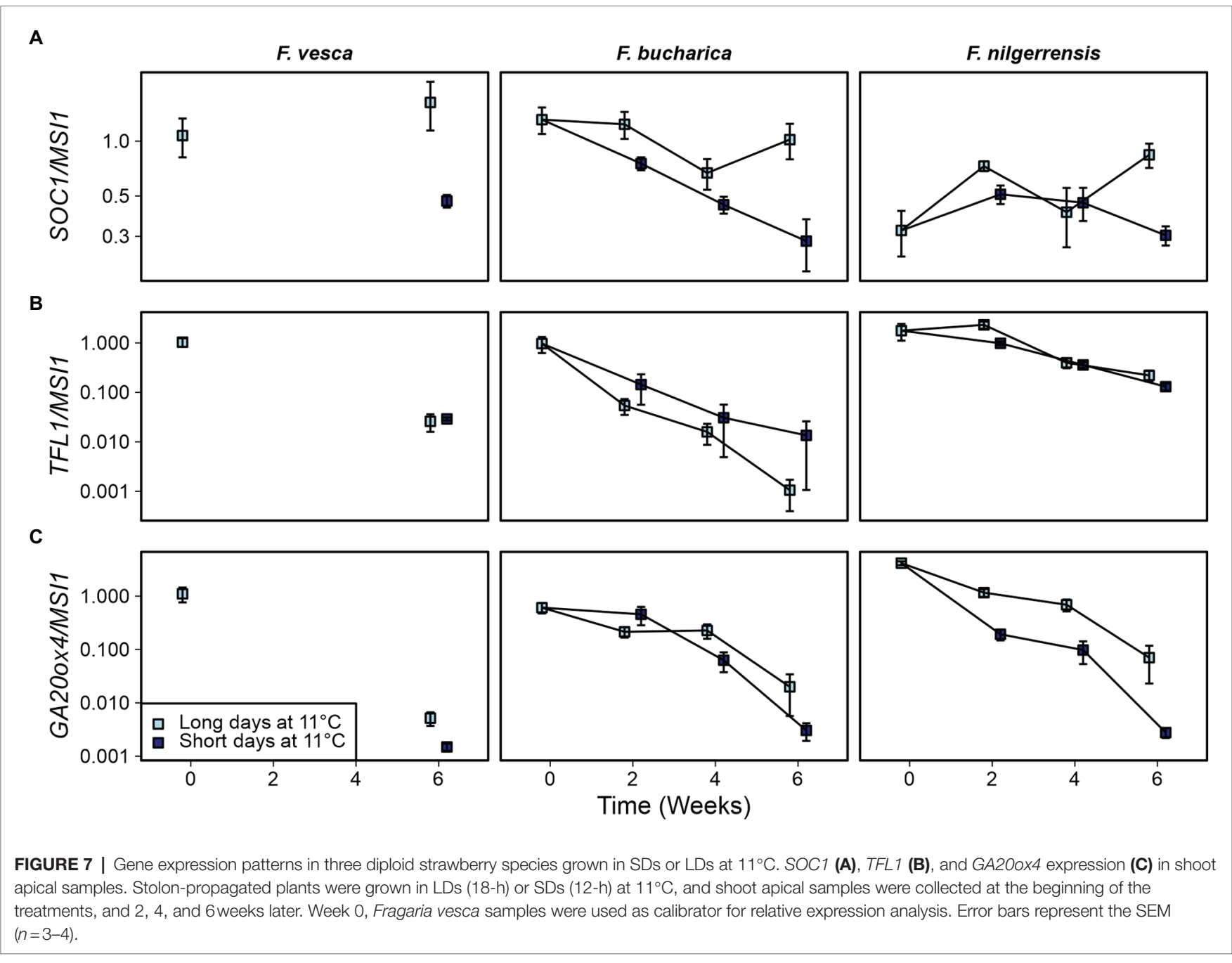

Corroborating with earlier studies in $\mathrm{F}$. vesca, stolon development ceased in all three species at $11^{\circ} \mathrm{C}$ regardless of the photoperiod, but this happened later in F. nilgerrensis than in other species (Figure 6A; Heide and Sønsteby, 2007; Andrés et al., 2021). The cessation of stolon development was associated with gradual downregulation of GA20ox4 expression in all three species indicating that GA20ox4 controls stolon development also in $F$. bucharica and $F$. nilgerrensis in these conditions. This finding is in line with the result of Andrés et al. (2021), who observed photoperiod-independent downregulation of FvGA20ox4 in the F. vesca accession "Hawaii-4" at cool temperature. It is notable that the expression of GA20ox4 does not follow the expression pattern of $S O C 1$ at $11^{\circ} \mathrm{C}$, not in our current experiment (Figure 7), nor in the earlier study by Andrés et al. (2021). These data indicate that, at $11^{\circ} \mathrm{C}, G A 200 \times 4$ expression is regulated by factors other than SOC1 in the three species.

\section{Different Pathways Regulate Branch Crown Development in the Three Species}

Although flower-inductive treatments promoted $\mathrm{BC}$ development in F. vesca, BC formation did not correlate with flowering in
F. bucharica and F. nilgerrensis, highlighting the diverged regulation of $\mathrm{BC}$ development in the three species. In $F$. nilgerrensis, SDs and cool temperature activated BC development independently of flowering, which was previously found also in late- and non-flowering F. vesca mutants with high FvTFL1 expression levels (Andrés et al., 2021). In F. bucharica, none of our tested conditions could promote BC development; although we witnessed clear photoperiodic and temperature regulation of flowering (Figures 3B, 6B). In F. bucharica grown at $18^{\circ} \mathrm{C}$, the lack of BCs was consistent with high FbGA20ox4 expression level in both SDs and LDs, and only flowering forced the topmost $\mathrm{AXB}$ to continue the growth of the leaf rosette sympodially. At $11^{\circ} \mathrm{C}$, however, $\mathrm{BCs}$ were absent regardless of the downregulation of FbGA20ox4 and the cessation of stolon formation. These findings suggest that $\mathrm{BC}$ development in F. bucharica was inhibited by factor(s) other than apical dominance, even after the downregulation of FbGA20ox4. This contrasts with findings in a stolonless ga20ox4 mutant of $F$. vesca that exhibits strong apical dominance and forms BCs only after flower induction or decapitation of the shoot tip (Andrés et al., 2021). Also, columnar apple trees show remarkably 
strong apical dominance, and almost all of their axillary shoots develop into reproductive short shoots (Kelsey and Brown, 1992), analogous to Fragaria BCs. These trees have ectopic MdDOXCo expression in shoots, in addition to its normal root-specific expression pattern, which hampers GA biosynthesis and leads to columnar phenotype (Okada et al., 2020; Watanabe et al., 2021).

Striking differences in BC development of F. bucharica and F. nilgerrensis may be adaptations to their native habitats. Fragaria bucharica is found at high altitude regions with very short growing season in Himalayas (Hummer et al., 2011; Johnson et al., 2014). Such alpine areas are usually dominated by species with low reproductive vigor that favor vegetative propagation over the comparatively riskier sexual reproduction (Billings and Mooney, 1968; Klimeš et al., 1997; Grime, 2001; Zhang et al., 2010). Therefore, the lack of branch crowns that limits the number of inflorescences to a maximum of one per plant may be an adaptive trait that makes vegetative reproduction through stolons a primary reproductive mode in F. bucharica. Fragaria nilgerrensis, in contrast, is native to habitats with very mild winters and long growing seasons in the Southeast Asia. Such conditions are more suitable for sexual reproduction, which may explain why this species develops abundant BCs in SDs in autumn/winter to enable the plant to form several inflorescences during the following growing season.

\section{CONCLUSION}

In this work, we provide the first phenotype and gene expression level analyses on the control of flowering and axillary meristem fates in several wild diploid Fragaria species under controlled environmental conditions. We show that the examined species feature a wide range of flowering responses, and variation in TFL1 regulation is the key to understanding the different responses. Moreover, we show that the environmental regulation of GA20ox4 varies in the three studied species, and this variation is associated with differences in stolon development. Finally, our results on BC development suggest diverged regulation of this process in F. vesca, F. bucharica, and F. nilgerrensis. To summarize, the diverse phenotypical responses (Supplementary Figure 3) provide an excellent starting point for carrying out further experiments to elucidate the genetic bases of these responses. We anticipate that such studies would provide new means to control yield formation in Rosaceous fruit and berry crops

\section{REFERENCES}

Andrés, J., Caruana, J., Liang, J., Samad, S., Monfort, A., Liu, Z., et al. (2021). Woodland strawberry axillary bud fate is dictated by a crosstalk of environmental and endogenous factors. Plant Physiol. 187, 1221-1234. doi: 10.1093/plphys/kiab421

Andri, S., Ken, A., Andreas, A., Nanina, A., Tomas, A., Chandima, A., et al. (2021). DescTools: Tools for Descriptive Statistics. R package version 0.99.44. Available at: https://cran.r-project.org/package $=$ DescTools

Bai, M., Liu, J., Fan, C., Chen, Y., Chen, H., Lu, J., et al. (2021). KSN heterozygosity is associated with continuous flowering of Rosa rugosa purple branch. Hortic. Res. 8:26. doi: 10.1038/s41438-021-00464-8 through (1) altered flowering characteristics based on modifications of TFL1 regulation, and (2) improved plant architectures by optimizing the balance between the formation of short and long shoots.

\section{DATA AVAILABILITY STATEMENT}

The original contributions presented in the study are included in the article/Supplementary Material, further inquiries can be directed to the corresponding author.

\section{AUTHOR CONTRIBUTIONS}

GF, JA, EK, and TH designed the experiments. KO provided diploid Fragaria species plant materials and participated in the selection of genotypes for the study. GF and JA carried out the experimental work and statistical analyses and drafted the manuscript. EK and TH supervised the work and edited the manuscript. All authors commented on and accepted the final manuscript version.

\section{FUNDING}

The research was funded by China Scholarship Council (Scholarship no. 201706510014 to GF) and Academy of Finland (grant no. 317306 to $\mathrm{TH}$ ).

\section{ACKNOWLEDGMENTS}

Doctoral Program in Plant Sciences at the University of Helsinki is acknowledged for JA's salaried $\mathrm{PhD}$ student position. We are also grateful to MSc student Kaiyue Qin about her help with phenotypic observations.

\section{SUPPLEMENTARY MATERIAL}

The Supplementary Material for this article can be found online at: https://www.frontiersin.org/articles/10.3389/fpls.2022.832795/ full\#supplementary-material

Bangerth, K. F. (2009). Floral induction in mature, perennial angiosperm fruit trees: similarities and discrepancies with annual/biennial plants and the involvement of plant hormones. Sci. Hortic. 122, 153-163. doi: 10.1016/j.scienta.2009.06.014

Billings, W. D., and Mooney, H. A. (1968). The ecology of artic and alpine plants. Biol. Rev. 43, 481-529. doi: 10.1111/j.1469-185X.1968.tb00968.x

Bors, R. H., and Sullivan, J. A. (2005). Interspecific hybridization of Fragaria moschata with two diploid species, F. nubicola and F. viridis. Euphytica 143, 201-207. doi: 10.1007/s10681-005-3496-9

Caruana, J. C., Sittmann, J. W., Wang, W., and Liu, Z. (2018). Suppressor of Runnerless encodes a DELLA protein that controls runner formation for asexual reproduction in strawberry. Mol. Plant 11, 230-233. doi: 10.1016/j.molp.2017. 11.001 
Charrier, A., Vergne, E., Dousset, N., Richer, A., Petiteau, A., and Chevreau, E. (2019). Efficient targeted mutagenesis in apple and first time edition of pear using the CRISPR-Cas9 system. Front. Plant Sci. 10:40. doi: 10.3389/ fpls.2019.00040

Costes, E., Crespel, L., Denoyes, B., Morel, P., Demene, M.-N., Lauri, P.-E., et al. (2014). Bud structure, position and fate generate various branching patterns along shoots of closely related Rosaceae species: a review. Front. Plant Sci. 5:666. doi: 10.3389/fpls.2014.00666

Edger, P. P., VanBuren, R., Colle, M., Poorten, T. J., Wai, C. M., Niederhuth, C. E., et al. (2017). Single-molecule sequencing and optical mapping yields an improved genome of woodland strawberry (Fragaria vesca) with chromosome-scale contiguity. GigaScience 7, 1-7. doi: 10.1093/gigascience/ gix124

Flachowsky, H., Szankowski, I., Waidmann, S., Peil, A., Tränkner, C., and Hanke, M. V. (2012). The MdTFL1 gene of apple (Malus $\times$ domestica Borkh.) reduces vegetative growth and generation time. Tree Physiol. 32, 1288-1301. doi: 10.1093/treephys/tps080

Freiman, A., Shlizerman, L., Golobovitch, S., Yablovitz, Z., Korchinsky, R., Cohen, Y., et al. (2012). Development of a transgenic early flowering pear (Pyrus communis L.) genotype by RNAi silencing of PcTFL1-1 and PcTFL1-2. Planta 235, 1239-1251. doi: 10.1007/s00425-011-1571-0

Grime, J. P. (2001). Plant strategies, vegetation processes, and ecosystem properties. Plant Sci. 161:813. doi: 10.1016/S0168-9452(01)00469-1

Heide, O. M., Rivero, R., and Sønsteby, A. (2020). Temperature control of shoot growth and floral initiation in apple (Malus $\times$ domestica Borkh.). CABI Agric. Biosci. 1, 1-15. doi: 10.1186/S43170-020-00007-6

Heide, O. M., and Sønsteby, A. (2007). Interactions of temperature and photoperiod in the control of flowering of latitudinal and altitudinal populations of wild strawberry (Fragaria vesca). Physiol. Plant. 130, 280-289. doi: 10.1111/j.1399-3054.2007.00906.x

Hummer, K. E., Bassil, N., and Njuguna, W. (2011). "Fragaria" in Wild Crop Relatives: Genomic and Breeding Resources: Temperate Fruits. ed. C. Kole (Berlin, Heidelberg: Springer Berlin Heidelberg), 17-44.

Hytönen, T., and Kurokura, T. (2020). Control of flowering and runnering in strawberry. Hortic. J. 89, 96-107. doi: 10.2503/hortj.UTD-R011

Hytönen, T., Palonen, P., Mouhu, K., and Junttila, O. (2004). Crown branching and cropping potential in strawberry (Fragaria $X$ ananassa Duch.) can be enhanced by daylength treatments. J. Hortic. Sci. Biotechnol. 79, 466-471. doi: 10.1080/14620316.2004.11511791

Iwata, H., Gaston, A., Remay, A., Thouroude, T., Jeauffre, J., Kawamura, K., et al. (2012). The TFL1 homologue KSN is a regulator of continuous flowering in rose and strawberry. Plant J. 69, 116-125. doi: 10.1111/j.1365-313X.2011.04776.x

Johnson, A. L., Govindarajulu, R., and Ashman, T. L. (2014). Bioclimatic evaluation of geographical range in Fragaria (Rosaceae): consequences of variation in breeding system, ploidy and species age. Bot. J. Linn. Soc. 176, 99-114. doi: 10.1111/boj.12190

Kelsey, D. F., and Brown, S. K. (1992). "McIntosh Wijcik": a columnar mutation of "McIntosh" apple proving useful in physiology and breeding research. Fruit Var. J. 46, 83-87.

Klimeš, L., Klimešová, J., Hendriks, R., and van Groenendael, J. (1997). “Clonal plant architecture: a comparative analysis of form and function", in The Ecology and Evolution of Clonal Plants. eds. H. de Kroon and J. van Groenendael (Leiden: Backhuys Publishers), 1-29.

Koskela, E. A., Kurokura, T., Toivainen, T., Sønsteby, A., Heide, O. M., Sargent, D. J., et al. (2017). Altered regulation of TERMINAL FLOWER 1 causes the unique vernalisation response in an arctic woodland strawberry accession. New Phytol. 216, 841-853. doi: 10.1111/nph.14734

Koskela, E. A., Mouhu, K., Albani, M. C., Kurokura, T., Rantanen, M., Sargent, D. J., et al. (2012). Mutation in TERMINAL FLOWER1 reverses the photoperiodic requirement for flowering in the wild strawberry Fragaria vesca. Plant Physiol. 159, 1043-1054. doi: 10.1104/pp.112.196659

Koskela, E. A., Sønsteby, A., Flachowsky, H., Heide, O. M., Hanke, M.-V., Elomaa, P., et al. (2016). TERMINAL FLOWER1 is a breeding target for a novel everbearing trait and tailored flowering responses in cultivated strawberry (Fragaria $\times$ ananassa Duch.). Plant Biotechnol. J. 14, 1852-1861. doi: 10.1111/pbi.12545

Kotoda, N., Iwanami, H., Takahashi, S., and Abe, K. (2006). Antisense expression of MdTFL1, a TFL1-like gene, reduces the juvenile phase in apple. J. Am. Soc. Hortic. Sci. 131, 74-81. doi: 10.21273/JASHS.131.1.74
Kurokura, T., Mimida, N., Battey, N. H., and Hytönen, T. (2013). The regulation of seasonal flowering in the Rosaceae. J. Exp. Bot. 64, 4131-4141. doi: $10.1093 /$ jxb/ert233

Kurokura, T., Samad, S., Koskela, E., Mouhu, K., and Hytönen, T. (2017). Fragaria vesca CONSTANS controls photoperiodic flowering and vegetative development. J. Exp. Bot. 68, 4839-4850. doi: 10.1093/jxb/ erx301

Li, W., Zhang, J., Sun, H., Wang, S., Chen, K., Liu, Y., et al. (2018). FveRGA1, encoding a DELLA protein, negatively regulates runner production in Fragaria vesca. Planta 247, 941-951. doi: 10.1007/s00425-017-2839-9

Liston, A., Cronn, R., and Ashman, T. L. (2014). Fragaria: a genus with deep historical roots and ripe for evolutionary and ecological insights. Am. J. Bot. 101, 1686-1699. doi: 10.3732/ajb.1400140

Mimida, N., Ureshino, A., Tanaka, N., Shigeta, N., Sato, N., Moriya-Tanaka, Y., et al. (2011). Expression patterns of several floral genes during flower initiation in the apical buds of apple (Malus $\times$ domestica Borkh.) revealed by in situ hybridization. Plant Cell Rep. 30, 1485-1492. doi: 10.1007/s00299-0111057-3

Mouhu, K., Kurokura, T., Koskela, E. A., Albert, V. A., Elomaa, P., and Hytönen, T. (2013). The Fragaria vesca homolog of SUPPRESSOR OF OVEREXPRESSION OF CONSTANS1 represses flowering and promotes vegetative growth. Plant Cell 25, 3296-3310. doi: 10.1105/tpc.113.115055

Okada, K., Wada, M., Takebayashi, Y., Kojima, M., Sakakibara, H., Nakayasu, M., et al. (2020). Columnar growth phenotype in apple results from gibberellin deficiency by ectopic expression of a dioxygenase gene. Tree Physiol. 40, 1205-1216. doi: 10.1093/treephys/tpaa049

Pfaffl, M. W. (2007). "Relative Quantification," in Real-time PCR. (ed.) M. Terfik Dorak. (NY, NewYork: Taylor \& Francis), 63-82.

Qiu, Y., Guan, S. C., Wen, C., Li, P., Gao, Z., and Chen, X. (2019). Auxin and cytokinin coordinate the dormancy and outgrowth of axillary bud in strawberry runner. BMC Plant Biol. 19:528. doi: 10.1186/s12870-019-2151-x

Rantanen, M., Kurokura, T., Jiang, P., Mouhu, K., and Hytönen, T. (2015). Strawberry homologue of TERMINAL FLOWER1 integrates photoperiod and temperature signals to inhibit flowering. Plant J. 82, 163-173. doi: 10.1111/tpj.12809

R Core Team (2021). R: A language and environment for statistical computing. R Foundation for Statistical Computing, Vienna, Austria. Available at: https:// www.R-project.org/

Sargent, D. J., Davis, T. M., Tobutt, K. R., Wilkinson, M. J., Battey, N. H., and Simpson, D. W. (2004). A genetic linkage map of microsatellite, genespecific and morphological markers in diploid Fragaria. Theor. Appl. Genet. 109, 1385-1391. doi: 10.1007/s00122-004-1767-9

Sønsteby, A., and Heide, O. M. (2019). Extreme short-day induction requirements for flowering in the late-flowering strawberry cultivar 'Malwina'. J. Hortic. Sci. Biotechnol. 95, 1-7. doi: 10.1080/14620316.2019.1679043

Staudt, G. (2005). Notes on Asiatic Fragaria species: IV. Fragaria iinumae. Bot. Jahrb. Syst. Pflanzengesch. Pflanzengeogr. 126, 163-175. doi: 10.1127/0006-8152/2005/0126-0163

Staudt, G. (2006). Himalayan species of Fragaria (Rosaceae). Bot. Jahrb. Syst. Pflanzengesch. Pflanzengeogr. 126, 483-508. doi: 10.1127/0006-8152/2006/0126-0483

Staudt, G. (2009). Strawberry biogeography, genetics and systematics. Acta Hortic. 842, 71-84. doi: 10.17660/ACTAHORTIC.2009.842.1

Staudt, G. D., Davis, T. M., and Gerstberger, P. (2003). Fragaria bifera Duch.: origin and taxonomy. Bot. Jahrb. Syst. Pflanzengesch. Pflanzengeogr. 125, 53-72. doi: 10.1127/0006-8152/2003/0125-0053

Sugiyama, N., Iwama, T., Inaba, Y., Kurokura, T., and Neri, D. (2004). Varietal differences in the formation of branch crowns in strawberry plants. J. Jpn. Soc. Hortic. Sci. 73, 216-220. doi: 10.2503/jjshs.73.216

Tenreira, T., Pimenta Lange, M. J., Lange, T., Bres, C., Labadie, M., Monfort, A., et al. (2017). A specific gibberellin 20-oxidase dictates the flowering-runnering decision in diploid strawberry. Plant Cell 29, 2168-2182. doi: 10.1105/tpc.16.00949

Watanabe, D., Takahashi, I., Jaroensanti-Tanaka, N., Miyazaki, S., Jiang, K., Nakayasu, M., et al. (2021). The apple gene responsible for columnar tree shape reduces the abundance of biologically active gibberellin. Plant J. 105, 1026-1034. doi: 10.1111/tpj.15084

Wilkie, J. D., Sedgley, M., and Olesen, T. (2008). Regulation of floral initiation in horticultural trees. J. Exp. Bot. 59, 3215-3228. doi: 10.1093/ jxb/ern 188

Zhang, J., Lei, Y., Wang, B., Li, S., Yu, S., Wang, Y., et al. (2020). The highquality genome of diploid strawberry (Fragaria nilgerrensis) provides new 
insights into anthocyanin accumulation. Plant Biotechnol. J. 18, 1908-1924. doi: $10.1111 /$ pbi.13351

Zhang, L., Turkington, R., and Tang, Y. (2010). Flowering and fruiting phenology of 24 plant species on the north slope of Mt. Qomolangma (Mt. Everest). J. Mt. Sci. 7, 45-54. doi: 10.1007/s11629-010$1107-2$

Conflict of Interest: TH was employed by company NIAB EMR.

The remaining authors declare that the research was conducted in the absence of any commercial or financial relationships that could be construed as a potential conflict of interest.
Publisher's Note: All claims expressed in this article are solely those of the authors and do not necessarily represent those of their affiliated organizations, or those of the publisher, the editors and the reviewers. Any product that may be evaluated in this article, or claim that may be made by its manufacturer, is not guaranteed or endorsed by the publisher.

Copyright (C) 2022 Fan, Andrés, Olbricht, Koskela and Hytönen. This is an openaccess article distributed under the terms of the Creative Commons Attribution License (CC BY). The use, distribution or reproduction in other forums is permitted, provided the original author(s) and the copyright owner(s) are credited and that the original publication in this journal is cited, in accordance with accepted academic practice. No use, distribution or reproduction is permitted which does not comply with these terms. 